\title{
Development of an ultra-sensitive method using nafion and multi-walled carbon nanotube coated glassy carbon electrode for atenolol determination
}

\author{
Atenolol tayini için nafion ve çok duvarlı karbon nanotüp kaplı camsı \\ karbon elektrot kullanılarak ultra hassas yöntem geliştirilmesi
}

\author{
Hilal ÇELIKK KAZICI ${ }^{*}$ iD \\ 1Department of Chemical Engineering, Faculty of Engineering, Yüzüncü Yıl University, Van, Turkey. \\ hcelik@eng.ankara.edu.tr
}

Received/Geliș Tarihi: 29.12.2016, Accepted/Kabul Tarihi: 25.12.2017

doi: $10.5505 /$ pajes.2017.54366

* Corresponding author/Yazıșllan Yazar Research Article/Araștırma Makalesi

\begin{abstract}
Atenolol (Scheme 1) is antihypertensive drug that form $\beta$-blocker group, which widely used in the treatment of hypertension In this study, the redox properties of the Tensinor drug used in blood pressure treatment were examined on modified glassy carbon electrode and the electrodes prepared by coating carbon nanotubes on this modified electrode. In order to investigate the effects of nafion coated multi-walled glass nanotube (MWCNT / NGCE) electrode response and nafion coated glassy carbon electrode (NGCE) and electrode responses of only glassy carbon electrode (GCE) surfaces on the support electrolyte, $p H$ and scan rate, the cyclic voltammetry (CV) and differential pulse voltammetry (DPV) methods were used. Atenolol (ATN) was observed in the BrittonRobinson (BR) buffer solution ( $p H$ 7.0) thereabouts $1.11 \mathrm{~V}(\mathrm{vsAg} / \mathrm{AgCl}$ (3.0 mol L-1 KCl). Voltammetric method reacted linear at a concentration range between 3x10-5 $\mu M$ and $9 \times 10-2 \mu M$ under optimum analytical experimental conditions. The results of Tensinor's limit of detection on the Britton-Robinson (BR) ( $p H=7)$ buffer were found to be $7.67 \times 10-5 \mathrm{mM}$ and $2.5 \times 10-4 \mathrm{mM}$, respectively. Additionally, in the study, interference effects experiments were performed with auxiliary substances used in the preparation of medicines and no negative effect was observed.
\end{abstract}

Keywords: Cyclic voltammetry, Atenolol, Carbon nano tube

\section{Introduction}

In the area of pharmaceutical research, the analytical examination of bulk drug agents, intermediates, pharmaceutical products, drug formulations, impurities and decomposition products, and biological samples containing the drugs and their metabolites is very important. From the beginning of the official pharmaceutical analysis, analytical analysis methods have taken part in the pharmacopoeia monographs with the aim of characterizing the quality of bulk drug materials by setting limits of their active agent content [1].

Electrochemistry is an area that analytical techniques with the emphasis of instrumentality simplicity, accuracy, low cost, and portability are quite important. With the help of these instruments it is possible to develop some very useful methods for specific applications. Especially, biologically important molecules and toxic metals can be investigated electroanalytically by voltammetric methods for their determination. Additionally, the mechanisms of electrode reactions can be also thrown light on by these methods. As a result of these, electroanalytical methods have many advantages that make them an attractive selection for pharmaceutical and environmental studies [2].
Öz

Atenolol (Sekil 1), hipertansiyon tedavisinde yaygin olarak kullanilan $\beta$ bloker grubunu oluşturan antihipertansif ilaçtır. Bu çalışmada; Tansiyon tedavisinde kullanılan Tensinör ilacının redoks özellikleri, modifiye camsı karbon elektrot ve bu modifiye elektrot üzerine karbon nano tüp kaplanarak hazırlanmış elektrotlarda incelenmiștir. Nafion kaplı çok duvarlı karbon nanotüp (MWCNT/NGCE) elektrot yanitı ile Nafion kaplı camsı karbon elektrot (NGCE) ve sadece camsı karbon elektrot (GCE) yüzeylerinin elektrot yanıtlarının destek elektroliti, $p H$, ve tarama hızı üzerine etkilerini araștırmak için Cevrimsel voltametri (CV) ve Diferansiyel puls voltametri (DPV) yöntemleri kullanılmıştır. Atenolol (ATN) Britton-Robinson (BR) tampon çözeltisinde ( $p H$ 7.0) $1.11 \mathrm{~V}$ (vsAg/AgCl $(3.0 \mathrm{~mol}$ L-1 KC1) civarında gözlenmiștir. Voltametrik yöntem, optimum analitik deney koșulları altında, 3x10-5 $\mu M-9 \times 10-2$ mM konsantrasyon aralığında lineer tepki göstermiştir. Britton-Robinson (BR) ( $\mathrm{pH}=7$ ) tamponundaki Tensinör belirme sinır sonuçları, sırasiyla $7.67 \times 10-5 \mathrm{mM}$ ve $2.5 \times 10-4 \mathrm{mM}$ olarak bulunmuștur. Ayrıca çalışmada ilaçların hazırlanmasında kullanılan yardımcı maddeler ile girișim etkisi deneyleri gerçekleștirilmiș ve olumsuz bir etkiye rastlanmamıştır.

Anahtar kelimeler: Çevrimsel voltametri, Atenolol, Karbon nano tüp

Developments of electrochemical methods especially in experimental studies for the analysis of drugs make these techniques be more preferable because of their plainness and comparatively shorter analysis time than other techniques. The use of various working electrodes such as mercury, carbon, and chemically modified electrodes for electroanalytical measurements has increased in recent years by the reason of their applicability for determining electroactive compounds that undergo oxidation or reduction reactions, which is very substantial in clinical and pharmaceutical studies [3].

Nafion, which is a modifier, is an anionic polyelectrolyte of perfluorinated sulfonated [4]. Nafion is used in electrochemistry a lot for changing an electrode with its very significant features like antifouling capacity, chemical inertness, thermal stability mechanical strength, and high permeability [5]-[8]. These qualities make the Nafion-coated glassy carbon electrode (NGCE) very intriguing for applications of $\beta$-adrenergic receptor blocking drugs in acidic aqueous media. Also, in this study, NGCE surface was covered coated with the multi-wall carbon nanotube (MWCNT). Carbon nanotubes (CNTs) are concentric graphitic cylinders closed at either end due to the presence of five-component rings [9]. MWCNT is formed from of a mixture of cylindrical tubes that 
are separate or are not helicity, thereby resembling turbostratic graphite. The arrangement of the carbon atoms in the hexagonal network of the multi-wall carbon nanotube is often helicoidal, resulting in the formation of chiral tubes. MWCNT is still appealing comparing with single-walled carbon nanotubes (SWCNT) due to their sufficient ability to be utilised with its high chemical stability and high mechanical strength in the industrial applications [10].

In analytical voltammetry usages of CNTs as electrode materials or modifiers of conventional working electrodes are quite common. In electrochemical measurements, CNTs have various advantages, i.e. the large active surface at electrodes of small dimensions, the enhanced electron transfer, or the electrocatalytic properties [11], [12].

Hypertension is a major health problem that affects a significant portion of the world population, and it was proved as a risk factor for coronary heart disease (CHD), heart failure, and stroke, peripheral arterial disease and kidney failure. $\beta$ adrenoceptor antagonists are drugs that reduce the risk of cardiovascular disease; In the past its utilising is proven to have hypertension treating and blood pressure lowering effects in clinical trials [13],[14]. Tensinor ${ }^{\circledR}$ is the trade name of the drug, in which active ingredient is the atenolol.

Atenolol (ATN) [4-[2-hydroxy-3-isopropylaminopropoxy]phenylacetamide] is a hydrophillic $\beta 1$-receptor blocking agent (Scheme 1). This $\beta$-adrenoceptor blocking agent has therapeutic features and data shows that it could be used in the treatment of various cardiovascular disorders such as angina pectoris, cardiac arrhythmia, and hypertension etc.

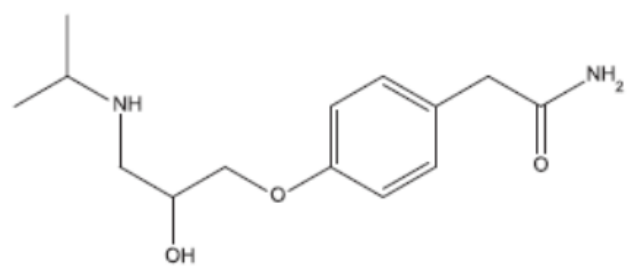

Scheme 1: Chemical structure of atenolol [15].

Frequent and wide use of atenolol resulted in using some analytical methods to determine atenolol including liquid chromatography (LC) [16], spectrophotometry [17], high-performance liquid chromatography (HPLC) [18],[19], gas chromatography (GC) and mass spectrometry in recent years [20].

The main aim of the current study is to examine voltammetric behavior of ATN especially with the use of NGCE/MWCNT, and then develop an electrochemical procedure for the sensitive, simple, and eco-friendly alternative to chromatography methods. Survey of literature revealed that no electroanalytical methods for determination of atenolol by using Nafion and multi-walled carbon nanotube coated glassy carbon electrode was reported

Since, it has been done very few studies [21-23] on this topic according to our literature review, the voltammetric determination of ATN is the focus of this study. In order that make a significant contribution to the literature in this field, cyclic (CV) and differential pulse (DP) voltammetric study was planned. Just after the effective parameters such as $\mathrm{pH}$ of supporting electrolyte solution, scan rate of potential, and type of working electrode were studied, the developed voltammetric procedure was applied for determining ATN in a pharmaceutical sample

\section{Experiments}

\subsection{Chemicals reagents and instruments}

Atenolol was obtained from Sigma-Aldrich (www.sigmaaldrich.com). Atenolol-containing tablets, marketed by different medical companies, were purchased from a local pharmacy in Turkey. Stock solution of ATN $\left(1.0 \times 10^{-2} \mathrm{mmolL}-1\right)$ was made ready in (ultra)purified water and kept in a refrigerator at $4 \mathrm{C}$. Nafion ( $5 \mathrm{wt} . \%$ solution in a mixture of lower aliphatic alcohols and water) used was provided from the Sigma-Aldrich. MWCNT and all other chemicals had qualities at analytical level, and were used as received. Britton-Robinson (BR) buffer solution was determined as supporting electrolyte for the $\mathrm{pH}$ study and separate evaluation of ATN. This solution was prepared by 0.04 mol L $\mathrm{L}^{-1}$ in acetic, orthophosphoric, and boric acids, with $\mathrm{pH}$ adjusted to 7.0 with a $2.0 \mathrm{~mol} \mathrm{~L}^{-1} \mathrm{NaOH}$ solution. All of the solutions used in the study were made ready with high purity water from Milli-Q water purification system.

The electrochemical experiments were performed with $\mathrm{CHI}$ 660 E potentiostat (Chen Hua Instrument Co., Shanghai, China). A three-electrode configuration involving NGCE (3-mm diameter) or a bare glassy carbon electrode (GCE), NGCE/MWCNT as a working electrode, the $\mathrm{Ag} / \mathrm{AgCl} / 3 \mathrm{M} \mathrm{KCl}$ reference electrode and Pt wire as a counter electrode, was used. All of these tests were done at room temperature (25 \pm 2 C).

\subsection{Synthesis of nafion coated-GCE and NGCE/MWCNT}

The GCE was pretreated by polishing its surface by means of emery paper using aqueous slurries of alumina powder $(0.3 \mu \mathrm{m})$ and thoroughly rinsed with water for making as clean surface as it could be. GCE was modified by $0.5 \%$ NAF (m/v) ethanol solution as the dispersing agent. Between the modifications, the GCE was polished with 0.05-micrometer alumina slurry with the help of a cloth for mirroring smoothness, rinsed thoroughly with deionized water, and had ultrasound in distilled water for 30 seconds. NAF-GCE surface and the solvent allowed evaporating at room temperature. Before the measurement, the modified electrode was rinsed with deionized water, and then scanned between $0 \mathrm{~V}$ and $2 \mathrm{~V}$ in sulfuric acid solution. The absorbed analyte on the surface of the modified electrode after measurement was removed via mechanical polishing by alumina powder. After then, multiwalled carbon nanotube (MWCNT) with $100 \mathrm{mg}$ was kept waiting in the mixture of $\mathrm{HNO}_{3}(33 \mathrm{~mL}, 1 / 1)$ and $\mathrm{H}_{2} \mathrm{SO}_{4}$ (17 mL, 1/1) for 20 hours (h). After it was kept waiting in the ultrasonic bath during 1 hour, it was heated by stirring at $100{ }^{\circ} \mathrm{C}$ for $4 \mathrm{~h}$. Subsequently it was washed with deionized water many times and was dried $4 \mathrm{~h}$ with IR lamp. Finally, MWCNT was dropped on to the NGCE surface.

\subsection{Experimental procedure}

The standard stock solution of ATN $\left(1.0 \times 10^{-2} \mathrm{mM}\right)$ was prepared. The working solutions with lower concentrations were prepared by further dilution of them via transferring with digital adjustable transfer pipettes.

Britton-Robinson (BR) buffer solutions were used as supporting electrolyte that has different $\mathrm{pH}$ values throughout the study. BR buffer solutions in the $\mathrm{pH}$ range between 2.0 and 
10.0 were prepared from mixture solution of $0.04 \mathrm{M} \mathrm{H}_{3} \mathrm{PO}_{4} 0.04$ $\mathrm{M} \mathrm{H}_{3} \mathrm{BO}_{3}$ and $0.04 \mathrm{M} \mathrm{CH}_{3} \mathrm{COOH}$ in deionized water. For each buffer solution, the $\mathrm{pH}$ of $50 \mathrm{~mL}$ mixture solution was adjusted to the desired value by adding $0.2 \mathrm{M} \mathrm{NaOH}$, and then it was diluted to $100 \mathrm{~mL}$ with deionized water. Also, sulfuric acid $\left(\mathrm{H}_{2} \mathrm{SO}_{4}\right)$ solutions were used as supporting electrolyte that has different concentrations, $0.1-0.5 \mathrm{~mol} \mathrm{~L}^{-1}$, throughout the study.

The supporting electrolyte was deaerated with argon for 5 minutes (min) prior to all of the electrochemical measurements. Between consecutive additions, the voltammetric cell content was also deaerated with argon for $30 \mathrm{~s}$.

The effects of $\mathrm{pH}$ on the anodic peak current values resulting from the oxidation of ATN were investigated using cyclic voltammetry technique. After the required volume of ATN standard solution had been added to the cell containing the supporting electrolyte which has different $\mathrm{pH}$ values in the range between 2.0 and 10.0 for each measurement, first of all the cyclic voltammogram values of $1.0 \times 10^{-2} \mathrm{mM}$ ATN were recorded under the same conditions.

In order to compare the obtained peak currents, both $\mathrm{CV}$ and DP voltammograms were also recorded at NGCE and MWCNT/NGCE in similar conditions.

The effective parameters for analytical performance, such as dynamic calibration range, limit of detection, limit of quantification, repeatability, etc. were optimized by considering the peak current of ATN obtained from DP voltammograms recorded between $0.15 \mathrm{~V}$ and $0.30 \mathrm{~V}$.

\subsection{Atenolol analysis in tensinor ${ }^{\circledR}$ drug}

The sample solution of Tensinor ${ }^{\circledR}$ drug was carefully prepared. For this purpose, ten tablets were grounded to a fine powder and homogenized. A Tensinor ${ }^{\circledR}$ tablet has a weight of $0.50 \mathrm{~g}$ (average of 10 tablets) and involves $50 \mathrm{mg}$ ATN per tablet. Then, this obtained powder $(0.50 \mathrm{~g})$ was added into $100 \mathrm{~mL}$ water containing about $0.2 \mathrm{M} \mathrm{HNO}_{3}$ for dissolving. The obtained heterogenic tablet mixture solution was filtered and washed. After that, obtained supernatant solution was diluted $200 \mathrm{~mL}$ water. The solutions of standard ATN and Tensinor ${ }^{\circledR}$ tablet were stored in the dark refrigerated environment.

The content of ATN tried to be determined in Tensinor ${ }^{\circledR}$ drug by being applied the voltammetric procedure under optimum experimental conditions. For this purpose, standard additions method was used. The standard addition is a useful method when the analyte is present in a complicated matrix and no ideal blank is available. In order to do that various solutions would be prepared with including the same unknown quantity, but different known quantities [24].

Under the optimum experimental condition, $15 \mu \mathrm{L}$ tablet solution was added into the voltammetric cell containing $5.0 \mathrm{~mL}$ BR buffer solution ( $\mathrm{pH} 7.0$ ), and DP voltammogram was recorded. Following this step, the known volumes of the standard ATN solution were consecutively added into the same voltammetric cell and then the voltammogram was recorded after each addition.

The standard addition calibration curve of the obtained current values from proposed method against concentrations of ATN standard solution added was plotted. Subsequently, linear regression analysis was done to find out the concentration of analyte. Here the slope (m) and y-intercept (b) of the calibration curve were made use of to measure the concentration.

\section{Results and discussion}

In connection with the aim of the study, first, type of working electrode was examined in detail by using CV and DPV techniques. Then, the resulting peak currents, which were obtained in the same supporting electrolyte (BR buffer solution containing, $\mathrm{pH}$ 7.0) at bare GCE, modified GCE (NGCE), and carbon nanotubes modified GCE (MWCNT/NGCE) were compared with each other. Finally, the performance of voltammetric technique was also investigated for determining ATN.

\subsection{Cyclic voltammetric studies using different working electrode}

To investigate the electrochemical behaviour of ATN, CV voltammogram of $1.0 \times 10^{-2} \mathrm{mM}$ ATN solution was recorded at scan rate $(v)$ of $20 \mathrm{mV} \mathrm{s}^{-1}$ in the BR buffer solution ( $\mathrm{pH} 7.0$ ) by using bare GCE, NGCE, and MWCNT/NGCE as the working electrode. The results obtained from these voltammograms (in the first scan) are given in Figure 1. When GCE was used as the working electrode, the peak current value of ATN was found very low according to its concentration. When NGCE was used as the working electrode, the peak current value of ATN was found much higher than that of bare GCE. As shown in Figure 1, when MWCNT/NGCE was used as the working electrode, the peak current value of ATN was higher than that of bare GCE and NGCE.

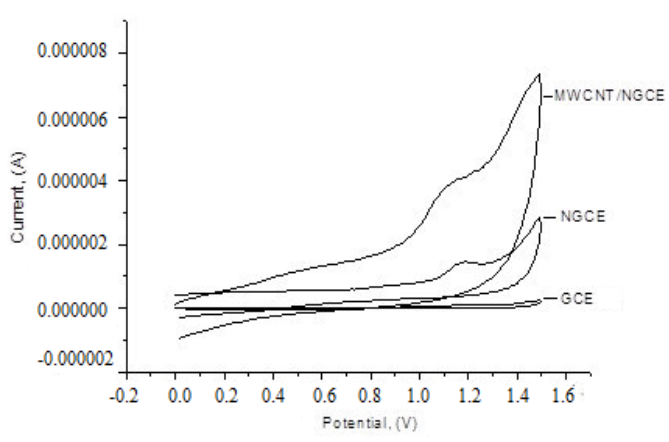

Figure 1: Cyclic voltammograms of measurements at GCE, NGCE, and MWCNT/NGCE ( $\left.v: 20 \mathrm{mVs}^{-1}\right)$ in the presence of $1.0 \times 10^{-2} \mathrm{mM}$ ATN in BR buffer solution ( $\left.\mathrm{pH} 7.0\right)$.

As a result the highest peak current value for ATN was obtained by using cyclic voltammetric technique at MWCNT/NGCE. In relation to this, studies on the investigation of cyclic and DP voltammetric behaviours of ATN were carried on by using MWCNT/NGCE. These studies including these optimization experiments were presented below.

\subsection{Effect of $\mathrm{pH}$ and supporting electrolyte}

Effect of $\mathrm{pH}$ was investigated by means of using cyclic voltammograms in BR buffer solutions $(2.0<\mathrm{pH}<10.0)$ at MWCNT/NGCE. The obtained cyclic voltammograms and results at a scan rate of $20 \mathrm{mVs}^{-1}$ are given in Figure 2a. It is clear that the intensity was increased to a high value at $\mathrm{pH} 7.0$, then the peak intensity decreases. Because the best result with respect to sensitivity accompanied with sharper response was obtained with $\mathrm{pH} 7.0$, it was selected for further experiments. Also, the effect of $\mathrm{pH}$ on the response of ATN $\left(1 \times 10^{-2} \mathrm{mM}\right)$ was evaluated using cyclic voltammetry $\left(20 \mathrm{mVs}^{-1}\right.$ scan rate $)$ 
employing MWCNT/NGCE. The effect of $\mathrm{pH}$ on peak potential and peak current of ATN was studied between 0.1-0.5 M sulfuric acid $\left(\mathrm{H}_{2} \mathrm{SO}_{4}\right)$ (Figure $\left.2 \mathrm{~b}\right)$.

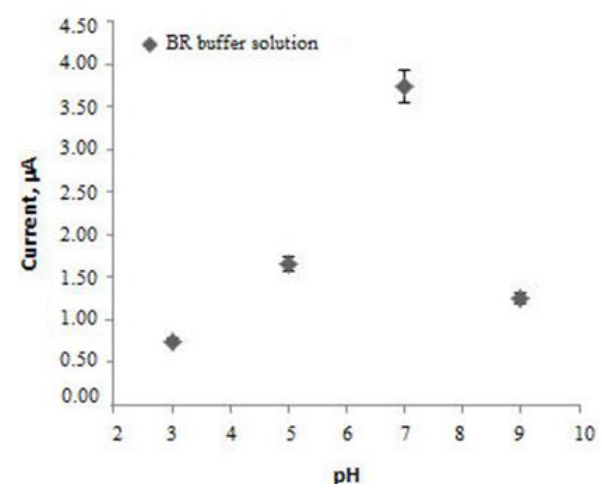

(a)

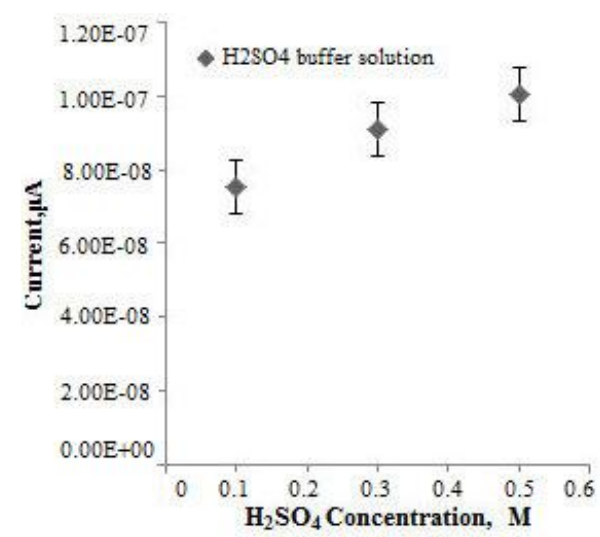

(b)

Figure 2(a): Results of cyclic voltammograms $\left(v: 20 \mathrm{mVs}^{-1}\right)$ in the presence of $1.0 \times 10^{-2} \mathrm{mM}$ ATN in BR buffer solution at different $\mathrm{pH}$ values $(2.0<\mathrm{pH}<10.0)$. (b): Results of cyclic voltammograms $\left(v: 20 \mathrm{mVs}^{-1}\right)$ in the presence of $1.0 \times 10^{-2} \mathrm{mM}$ ATN in sulfuric acid $\left(\mathrm{H}_{2} \mathrm{SO}_{4}\right)$ solution at different concentration values (0.1-0.5 M).

In this region, the increase of peak current and sulfuric acid concentration, and ease of oxidation was observed. Besides, peak potentials of ATN shifted toward lesser values ( + ) as $\mathrm{pH}$ of the medium growed. The $\mathrm{pH}$ of the supporting electrolytes affects peak current and potential of ATN, which indicates that the proton plays a role in oxidation reactions. In the working environment, $\mathrm{pH}=7.0 \mathrm{BR}$ solution was selected for the most obvious, sharp peaks and the maximum current was observed as $+1.2 \mathrm{~V}$.

\subsection{Effect of scan rate}

The scan rate has an important effect on the peak currents. The effect of the scan rate on peak current was found in the range of $10 \mathrm{mVs}^{-1}$ to $100 \mathrm{mVs}^{-1}$ for $1.0 \times 10^{-2} \mathrm{mM}$ ATN. The voltammogram was recorded. As it can be seen in Figure 3. The anodic peak of ATN grows with increasing scan rate. However, no cathodic peak of ATN was observed on the reverse scan.

The linear change of peak current values with the square root of the scan rate was also observed in BR buffer solutions (pH 7.0), in the range of $10-100 \mathrm{mVs}^{-1}$ (Figure 4).

Equation is as follows:
The linear regression equations i $(\mu \mathrm{A})=2 \times 10^{-7} \mathrm{v}^{1 / 2}\left(\left(\mathrm{mV} \mathrm{s}^{-1}\right)^{1 / 2}\right)$ $+3 \times 10^{-6}$ which have a correlation coefficient of $\mathrm{R}^{2}=0.9946$ indicate that the oxidation reaction of ATN was also controlled by diffusion in the BR buffer solution ( $\mathrm{pH}$ 7.0). In addition, the peak potential values shifted to more positive values with increasing in scan rate.

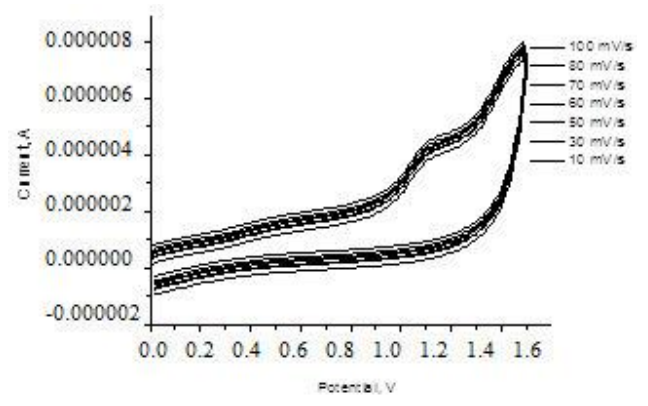

Figure 3: Cyclic voltammograms of $1.0 \times 10^{-2} \mathrm{mM}$ ATN at the different scan rates $\left(10<v<100 \mathrm{mVs}^{-1}\right)$ in BR buffer solution $(\mathrm{pH}=7.0)$.

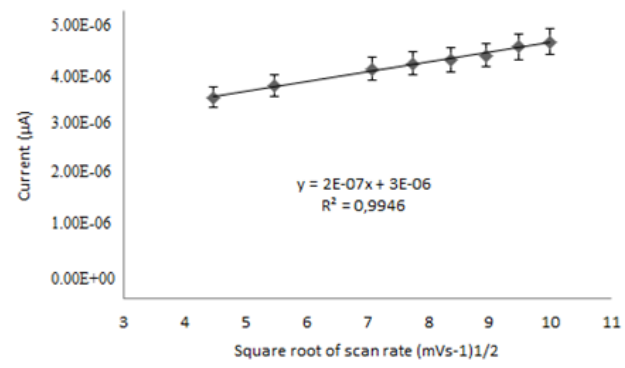

Figure 4: $\mathrm{v}^{1 / 2}-$ ip in $1.0 \times 10^{-2} \mathrm{mM}$ ATN $\mathrm{pH}=7$ BRT solution.

\subsection{Analytical characteristics and validation parameters}

A calibration study was carried out over the range of $8 \times 10^{-8}-9 \times 10^{-2} \mathrm{mM}$ ATN concentration to establish a reliable analytical response in the determination of ATN, under optimized conditions using a MWCNT/NGCE. These DP experiments were carried out at the scan rate of $20 \mathrm{mVs}^{-1}$, in BR buffer solution ( $\mathrm{pH}$ 7.0) (Figure 5). When the obtained peak currents were plotted against concentrations of ATN, the linear segment was observed as of $3 \times 10^{-5}-9 \times 10^{-2} \mathrm{mM}$.

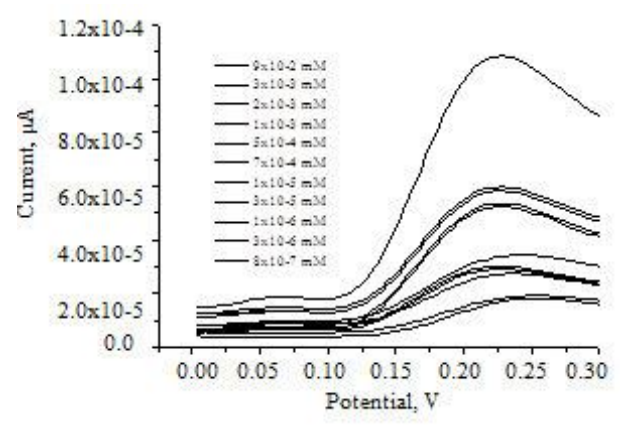

Figure 5: Dependence of the DP voltammograms with ATN concentration $9 \times 10^{-2} \mathrm{mmol} \mathrm{L}^{-1}$ to $8 \times 10^{-8} \mathrm{mmol} \mathrm{L}^{-1}$ in universal buffer, $\mathrm{pH} 7, \mathrm{a}=50 \mathrm{mV}, \mathrm{v}=20 \mathrm{mVs}^{-1}$.

addition graph was plotted against the calculated concentration of standard ATN in the cell (Figure 7).

$$
\mathrm{i}(\mu \mathrm{A})=12737 \mathrm{C}_{\mathrm{ATN}}(\mathrm{M})+20.363\left(\mathrm{R}^{2}=0.99\right)
$$


Where $\mathrm{i}$ is the peak current and $\mathrm{C}$ is the concentration of ATN.

In order to evaluate the limit of detection (LOD), we fitted a straight line $i(\mu \mathrm{A})=12737 \mathrm{C}_{\mathrm{ATN}}(\mathrm{M})+20.363$ to the data in Figure 6, and applied the widely-used criterion for LOD [25].

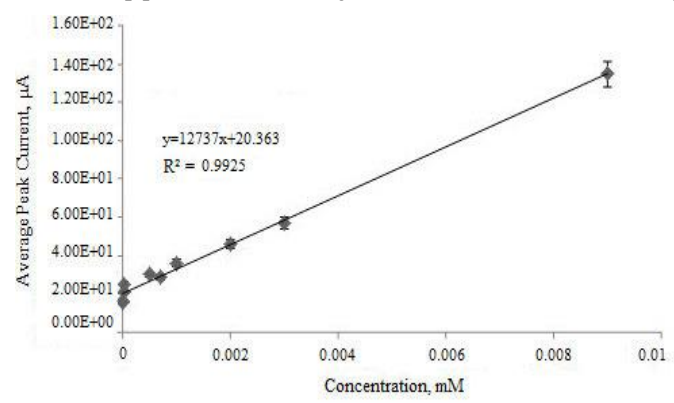

Figure 6: Calibration curves $\left(\mathrm{i}=\mathrm{f}\left(\mathrm{C}_{\mathrm{ATN}}\right)\right)$ for determination of ATN at MWCNT/NGCE. Data were extracted from Figure 5.

The LOD and limit of quantification (LOQ) were calculated as $7.67 \times 10^{-5} \mathrm{mmolL}^{-1}$ and $2.55 \times 10^{-4} \mathrm{mmolL}^{-1} \mathrm{ATN}$, respectively, using the equation $\mathrm{LOD}=3 \mathrm{sy} / \mathrm{x} / \mathrm{m}$ and $\mathrm{LOQ}=10 \mathrm{sy} / \mathrm{x} / \mathrm{m}$, where $\mathrm{m}$ is the slope of the first calibration plot and $s_{y / x}$ is the standard error of the estimate of the calibration curve (Eq. 2).

$$
S y_{/ x}=\sqrt{\frac{\left[\sum_{i=1}^{N}\left(y_{i}-\hat{y}\right)\right]^{2}}{N-2}}
$$

Where $y_{i}$ is measured signal, $\hat{y}$; concentration of measured for this signal and $N$ is the number of points in the calibration graph.

The linear calibration range of the proposed method has comparativeness quality with or is better than mentioned study (Table 1).

Table 1: Comparison of the proposed with another method.

\begin{tabular}{ccccc}
\hline Method & $\begin{array}{c}\text { Analytical } \\
\text { Range, } \mu \mathrm{M}\end{array}$ & $\begin{array}{c}\text { LOD } \\
\mu \mathrm{M}\end{array}$ & $\begin{array}{c}\text { LOQ } \\
\mu \mathrm{M}\end{array}$ & Ref. \\
\hline $\begin{array}{c}\text { Bare graphite- } \\
\text { polyurethane } \\
\text { composite } \\
\text { electrode }\end{array}$ & $4-100$ & 3.16 & 10.5 & {$[26]$} \\
$\begin{array}{c}\text { C60-modified } \\
\text { glassy carbon } \\
\text { electrode }\end{array}$ & $250-1500$ & 160 & 530 & {$[22]$} \\
$\begin{array}{c}\text { MOR-modified CPE } \\
\text { Nanogold modified } \\
\text { indium tin oxide } \\
\text { (ITO) }\end{array}$ & $0.4-1000$ & 0.13 & 0.43 & {$[28]$} \\
MWCNT/NGCE & $\mathbf{3 \times 1 0 - 5 - 9 0}$ & $\mathbf{0 . 0 7 6 7}$ & $\mathbf{0 . 2 5 5}$ & $\begin{array}{c}\text { This } \\
\text { work }\end{array}$ \\
\hline
\end{tabular}

\subsection{Real sample analysis}

Sample solutions of Tensinor $®$ Drug (in the tablet form) were prepared with ten tablets. The voltammograms were recorded under optimum working conditions (BR buffer solution $\mathrm{pH}$ 7.0) by applying standard addition method. The standard addition graph was plotted against the calculated concentration of standard ATN in the cell (Figure 7).

The data were in well concordance with the content marked in the label of Tensinor $®$ (Table 2).
Table 2: Determining atenolol in pharmaceutical preparation using MWCNT/NGCE electrode.

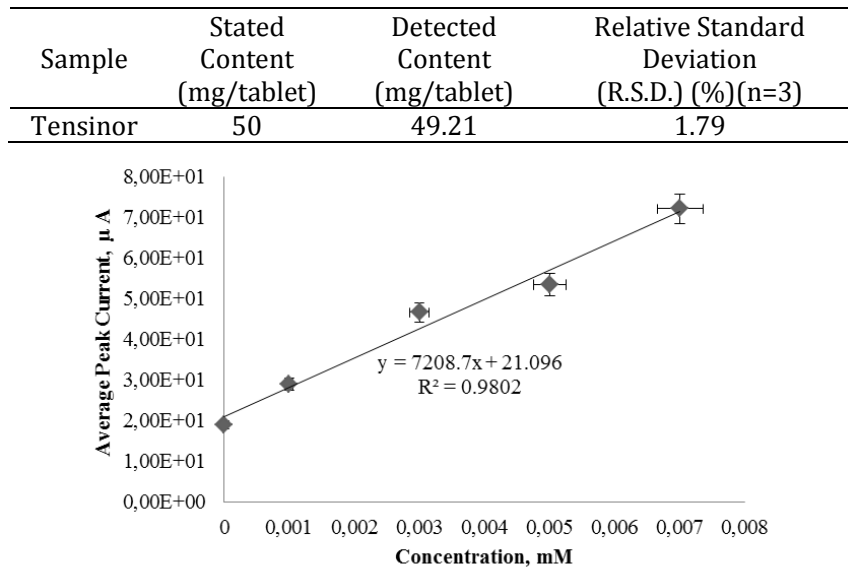

Figure 7: The standard addition graph for to determine ATN in Tensinor ${ }^{\circledR}$ tablet.

\subsection{Effect of excipients}

The outcomes of the use of some often-used ingredients of the pharmaceutical preparations were studied for possible analytical applications of this method. The effects of these excipients on the differential pulse voltammetric response were carried out by testing sample solutions with a fixed amount of ATN $\left(1.0 \times 10^{-2} \mathrm{mmolL}^{-1}\right)$ containing with different excess quantities of each excipient, in the same experiment environment.

The experimental results (Table 3) showed that 100 times excess of sucrose, maltose, and sorbitol did not affect the voltammetric signal of ATN. Thus, the procedures were able to determine the ATN in the existence of excipients, and thus it was understood that it can be considered as specific.

Table 3: Influence of potential excipients on the voltammetric response of $1.0 \times 10^{-2} \mathrm{mM}$ ATN.

\begin{tabular}{ccc}
\hline $\begin{array}{c}\text { Excipients }(1 \mathrm{mM})+\text { ATN } \\
\left(1.0 \times 10^{-2} \mathrm{mM}\right)\end{array}$ & $\begin{array}{c}\text { Potential } \\
(\mathrm{V})\end{array}$ & $\begin{array}{c}\text { Change } \\
(\%)\end{array}$ \\
\hline ATN & 0.224 & 0 \\
Sucrose+ ATN & 0.229 & 2.2 \\
Maltose+ ATN & 0.231 & 3.1 \\
Sorbitol+ ATN & 0.227 & 1.3 \\
\hline
\end{tabular}

\section{Conclusion}

In this study, it was aimed to investigate the voltammetric behavior of ATN and develop a method for the determination of ATN, especially using MWCNT/NGCE. For this aim, it was carried out an investigation on bare GCE, NGCE, and MWCNT/NGCE in BR buffer solutions using both the cyclic and DP modes. The effective parameters such as $\mathrm{pH}$ of supporting electrolyte solution, scan rate of potential, and type of working electrode were determined.

The proposed voltammetric procedure was successfully applied to the direct determination of ATN in Tensinor ${ }^{\circledR}$ drug. A very low-cost and simple DP voltammetric procedure was developed for the determination of ATN. It was found that the voltammetric methods reported by Priscila et al. (2007) have lower LOD value than the proposed method [26]. This low LOD value arises from the use of a controlled-growth mercury drop electrode. However, the use of mercury has been increasingly 
abolished from analytical methodology due to its toxicity in recent years. Main advantage is that the excipients do not intervene and hence separation is not necessary. Moreover, the present method is acceptable for pharmacokinetic studies.

\section{Acknowledgements}

This work was financially supported by Scientic and Technological Research Council of Turkey (TUBITAK) (Project No: 1919B011501676).

\section{References}

[1] Sudha T, Krishana KV, Nukala PCS, Saloman RT, Ganesan V. "Method development and validation". Journal of Advanced Pharmacy Education \& Research, 2(3), 146-176, 2012.

[2] Wang J. Analytical Electrochemistry, New Jersey, USA, Wiley-VCH Pub. 2006.

[3] Gupta, VK, Jain R, Radhapyari K, Jadon N, Agarwal S. "Voltammetric techniques for the assay of pharmaceuticals". Analytical Biochemistry, 408(2), 179196, 2011.

[4] Andrieux CP, Audebert P, Divisia-Blohorn B, Aldebert P, Michalak F. "Electrochemistry in Hydrophobic Nafion Gels". Journal of Electroanalytical Chemistry, 296(1), 117 139, 1990.

[5] Svancara I, Vytras K, Kalcher K, Walcarius A, Wang J. "Carbon paste electrodes in facts, numbers, and notes: a review on the occasion of the 50-years jubilee of carbon paste in electrochemistry and electroanalysis". Electroanalysis, 21(1), 7-28, 2009.

[6] Guo S, Wu X, Zhou J, Wang J, Yang B, Ye B. “MWNT/Nafion composite modified glassy carbon electrode as the voltammetric sensors for sensitive determination of 8hydroxyquinoline in cosmetic". Journal of Electroanalytical Chemistry, 655(1), 45-49, 2011.

[7] Xie X, Gan T, Sun D, Wu K. "Application of multi-walled carbon nanotubes/nafion composite film in electrochemical determination of $\mathrm{Pb}^{+2 "}$. Fullerenes, Nanotubes and Carbon Nanostructures, 16(2), 103-113, 2008.

[8] Huang KJ, Liu X, Xie WZ, Yuan HX. "Electrochemical behavior and voltammetric determination of norfloxacin at glassy carbon electrode modified with multi walled carbon nanotubes/Nafion". Colloids and Surfaces B: Biointerfaces. 64(2), 269-274, 2008.

[9] Iijima S. "Carbon nanotubes: past, present, and future". Physica B: Condensed Matter. 323(1-4), 1-5, 2002.

[10] Tanaka K, Yamabe T, Fukui K. "The Science and Technology of Carbon Nanotubes". Elsevier. 1999.

[11] Trojanowicz M. "Analytical applications of carbon nanotubes: A review". Trends in Analytical Chemistry, 25(5), 480-89, 2006.

[12] Kazici HC, Salman F, Caglar A, Kivrak H, Aktas N. "Synthesis, characterization, and voltammetric hydrogen peroxide sensing on novel monometallic (Ag, Co/MWCNT) and bimetallic (AgCo/MWCNT) alloy nanoparticles". Fullerenes, Nanotubes and Carbon Nanostructures, 26 (3), 145-151, 2018.

[13] Kannel WB. "Blood pressure as a cardiovascular risk factor: prevention and treatment”. JAMA, 275(20), 15711576, 1996.

[14] Ritter JM. "Nebivolol: Endothelium-Mediated Vasodilating Effect". Journal of Cardiovascular Pharmacology, 38(3), 13-16, 2001.
[15] Winkler H, Ried W, Lemmer B. "High-performance liquid chromatographic method for the quantitative analysis of the aryloxypropanolamines propranolol, metoprolol and atenolol in plasma and tissue". Journal of Chromatography B: Biomedical Sciences and Applications, 228, 223-234, 1982.

[16] Khataee A, Lotfi R, Hasanzadeh A, Iranifam M, Joo SW. "Flow-injection chemiluminescence analysis for sensitive determination of atenolol using cadmium sulfide quantum dots". Spectrochimica Acta Part A: Molecular and Biomolecular Spectroscopy. 157, 88-95, 2016.

[17] Amiri M, Amali E, Nematollahzadeh A. "Poly-dopamine thin film for voltammetric sensing of atenolol". Sensors and Actuators B: Chemical, 216, 551-557, 2015.

[18] Wilson MJ, Ballard KD, Walle T. "Preparative resolution of the enantiomers of the $\beta$-blocking drug atenolol by chiral derivatization and high-performance liquid chromatography". Journal of Chromatography B: Biomedical Sciences and Applications, 431, 222-227, 1988.

[19] Eaga CM, Somagoni JM, Maddi SR, Reddy S, Yamsani MR. "New chiral reverse phase hplc method for determination of atenolol enantiomers in pharmaceutical formulations". International Journal of Pharmaceutical Sciences Review and Research, 4(1), 22-26, 2010.

[20] Angier MK, Lewis RJ, Chaturvedi AK, Canfield DV. "Gas Chromatographic/Mass Spectrometric Differentiation of Atenolol, Metoprolol, Propranolol, and an Interfering Metabolite Product of Metoprolol". Journal of Analytical Toxicology, 29(6), 517-521, 2005.

[21] Shadjou N, Hasanzadeh M, Saghatforoush L, Mehdizadeh $\mathrm{R}$, Jouybanb A. "Electrochemical behavior of atenolol, carvedilol and propranolol on copper-oxide nanoparticles". Electrochimica Acta, 58, 336- 347, 2011.

[22] Rajendra NG, Sudhanshu PS. "Voltammetric determination of atenolol at $\mathrm{C}_{60}$-modified glassy carbon electrodes", Talanta, 69(4), 932-937, 2006.

[23] Mohamed K, Ahmed AK, Farouk AR, Gamal AS, Hanaa MAW, Craig EB. "Simultaneous voltammetric determination of antihypertensive drugs nifedipine and atenolol utilizing $\mathrm{MgO}$ nanoplatelet modified screenprinted electrodes in pharmaceuticals and human fluids". Sensors and Actuators B: Chemical, 252, 1045-1054, 2017.

[24] Rieger PH. Electrochemistry. $2^{\text {nd }}$ ed. USA, Chapman \& Hall, 1993

[25] Kazici HC, Salman F, Kivrak HD. "Synthesis of Pd-Ni/C bimetallic materials and their application in nonenzymatic hydrogen peroxide detection", Materials Science-Poland, 35 (3), 660-666, 2017.

[26] Cervini P, Ramos LA, Cavalheiro ETG. "Determination of atenolol at a graphite-polyurethane composite electrode". Talanta, 72(1), 206-209, 2007.

[27] Arvand M, Vaziri M, Vejdani M. "Electrochemical study of atenolol at a carbon paste electrode modified with mordenite type zeolite". Materials Science and Engineering: C, 30(5), 709-714, 2010.

[28] Goyal RN, Gupta VK, Oyama M, Bachheti N. "Differential pulse voltammetric determination of atenolol in pharmaceutical formulations and urine using nanogold modified indium tin oxide electrode". Electrochemistry Communications, 8(1), 65-70, 2006. 